Bioscientia Medicina: Journal of Biomedicine \& Translational Research

Journal Homepage: www.bioscmed.com

\title{
Effects of Artemisia Vulgaris Extract on Apoptotic Index and Caspase-8
} Jonathan Sugiharto ${ }^{*}$, Selamat Budijitno ${ }^{2}$

${ }^{1}$ General Surgery Resident, Faculty of Medicine Diponegeoro University/Dr. Kariadi General Hospital, Semarang, Indonesia

2 Surgical Oncology Staff, Departement of Surgery, Diponegoro University / Dr. Kariadi General Hospital, Semarang, Indonesia

\section{A R T I C L E I N F O}

\section{Keywords:}

Artemisia vulgaris

Breast adenocarcinoma

Apoptotic index

Caspase-8

\section{*Corresponding author:}

Jonathan Sugiharto

\section{E-mail address:}

\section{jonathansugiharto89@gmail.com}

All authors have reviewed and approved the final version of the manuscript.

\section{https://doi.org/10.37275/bsm.v6i4.486}

\begin{abstract}
A B S T R A C T
Background. Worldwide incidence of breast cancer is still high. Surgical intervention is mainly used as primary treatment with other supplementary modality such as chemoterapy, radioterapy, and immunotherapy such as Artemisia vulgaris (AV). This study was aimed to analyze the increase in apoptotic effect response of adriamycin-cyclophosphamide on $\mathrm{C} 3 \mathrm{H}$ mice model of adenocarcinoma breast cancer provided with Artemisia vulgaris extract. Methods: This research is a post-test only control group design. Twenty four $\mathrm{C} 3 \mathrm{H}$ mice were randomly selected and put into 4 groups: $\mathrm{K}$ (control group), P1 (Chemoterapy only), P2 (extract only) and P3 (chemoterapy-extract combination). Breast adenocarcinoma was taken from inoculated donor mice. Chemoterapy regiment of $0.18 \mathrm{mg}$ Adriamycin and $1.8 \mathrm{mg}$ Cyclophosphamide were given in 2 cycles. Thirteen miligrams $(0.2 \mathrm{~mL})$ of AV extract was given orally once daily. Apoptotic index and Caspase-8 expression were graded with immunohistochemistry stain. Results: Mean value of p53 and caspase- 8 expression in $\mathrm{K}, \mathrm{P} 1, \mathrm{P} 2$, P3 groups were $22,06+1,73,37,16+1,20,24,60+$ $1,08,39,78+1,19$ and $17.16+1,28,26,20+1,11,24.60+1,08,39,78+1,19$, respectively. Statistical analysis showed significant differences in apoptotic index between group K vs P1, P3 ( $p=0,001)$, P1 vs P2 ( $p=0,001)$, P1 vs P3 ( $p=0,035)$, P2 vs P3 ( $=0,001)$ and for Caspase- 8 between $K$ vs P1, P3 ( $=0,001)$, K vs P2 $(p=0,048), P 1$ vs P2 $(p=0,001), P 1$ vs P3 $(p=0,039)$, P2 vs P3 $(p=0,001)$. We found a significant correlation between apoptotic index and Caspase-8 expression. ( $p=0,047$ and $r=0,883)$. Conclusion: Artemisia vulgaris can increase the adriamycin-cyclophosphamide chemoterapy effectiveness on $\mathrm{C} 3 \mathrm{H}$ Mice Model of Breast Adenocarcinoma.
\end{abstract}

\section{Introduction}

Breast cancer is still one of the major female health burden in the world. In 2009 there were 192,370 new invasive breast cancer cases and 62,280 in situ cancer cases in USA alone. In Indonesia, breast cancer has become the leading case od malignant tumor followed by cervical cancer, with incidence rate occured in 100 per 100,000 women. ${ }^{1}$ Breast cancer incidence in Indonesia was $12 / 100,000$ women with high mortality rate $(27 / 100,000$ or $18 \%$ of all mortality in women). In men, there is $1 \%$ incidence that breast cancer will occur. More than $80 \%$ cases in Indonesia were found in advanced stages, when treatment has a lower success rate. ${ }^{2}$

Breast cancer therapy consisted of surgery, radiotherapy, chemotherapy, and hormonal therapy. Chemotherapy is a treatment method using chemical drugs that destroys or inhibits cancer cells growth. The most used chemoterapy regiment are Fluorouracil, Doxorubicin and Cyclophosphamide (FAC); Fluorouracil, Epirubicin and Cyclophosphamide (FEC); 
Doxorubicin and Cyclophosphamide (AC) and Cyclophosphamide, Methotrexate and Fluorouracil $(\mathrm{CMF})$. Chemoterapy success rate based on the postchemoterapy objective response rate, (Partial Response and Complete Response - CR/PR), is only 20-40\%. There are also adverse effects on liver, kidney, heart, and other organs, and also immunosuppresion. ${ }^{3-4}$.

Artemisia vulgaris is one of the herbal agent used as chemoterapy adjuvant agent. This plant has a selective cytotoxic effect on cancer cells and had been widely used as adjuvant agent on colorectal, renal, prostate, liver, pancreatic, skin, and gastric cancer. Artemisia vulgaris extract has terpenoid (artemisinin, artesunate), flavonoid, tanin and coumarin (scopoletin). Artemisinin and artesunate have been widely used as antimalaria ${ }^{5}$, but recent studies found cytotoxic activity in these substance against cancer cells by inducing apoptosis and inhibiting angiogenesis, cancer cell cycles' disruption, and selective free radical toxicity. ${ }^{6}$

This study aims to prove the effectivity of Artemisia vulgaris extract as chemotherapy adjuvant agent against breast adenocarcinoma by measuring the increase in apoptotic index and decrease in protein retinoblastoma in $\mathrm{C} 3 \mathrm{H}$ mice breast cancer model treated with Adriamycin-Cyclophosphamide. We hope that this study supported the use of Artemisia vulgaris as chemotherapy adjuvant in breast cancer treatment.

\section{Methods}

This study has been approved by Ethical Commitee of Faculty of Medicine, Diponegoro University, Semarang (KEPK) with Ethical Clearance No. 04/EC/H/FK-RSDK/II/2018. This study was a posttest only control group design done in LPPT I
Laboratory Faculty of Medicine Gadjah Mada University for 5 months.

Twenty four $\mathrm{C} 3 \mathrm{H}$ mice obtained from local farmer in Bogor were our study subject. We included 8 weeks female mice weighing 20 - 30 grams after acclimatization, and without any anatomic abnormality. Mice that didn't develop cancer after inoculation or mice that got sick were excluded from our study. Mice were randomly selected and divided into 4 groups: $\mathrm{K}$ (control) group which got inoculated with cancer cells and didn't get any treatment, $\mathrm{P} 1$ group (chemotherapy group) which received AdriamycinCyclophosphamide treatment, P2 group (extract) group which given by Artemisia vulgaris extract, and P3 (combination) group which provided with combination of chemotherapy and plant-extract treatment. We used $0.18 \mathrm{mg}$ of Adriamycin and $1.8 \mathrm{mg}$ of Cyclophosphamide given in 2 cycles for our regiment. Thirteen miligrams $(0.2 \mathrm{~mL})$ of Artemisia vulgaris extract was given orally once a day. For apoptotic index and Caspase- 8 expression measurement, we took a sample of cancer tissue after experiment and made a histopathologic slide with $\mathrm{HE}$ and immunohistochemistry staining.

Statistical analysis was done using SPSS 21.0 for Windows. Correlation between apoptotic index and Caspase- 8 measured with Pearson test, with the result being significant if $\mathrm{p}$ value $<0.05$.

\section{Results}

According to Aihara M., et.al. apoptotic bodies were counted per 100 tumor cells with 400x magnification. Table below shown that apoptotic index in $\mathrm{K}$ group $(2,18$ $\pm 0,80)$ was lower than P2 $(3,34 \pm 0,51)$, and P1 $(18,00$ $\pm 1,58)$ was lower P3 $(20,32 \pm 1,39)$.

Table 1. Apoptotic index descriptive analysis

\begin{tabular}{|c|c|c|c|c|c|}
\hline Group & N & Min (\%) & Max (\%) & Mean \pm SD (\%) & Median (\%) \\
\hline K & 5 & 1.10 & 3.10 & $2.18 \pm 0.80$ & 2.30 \\
\hline P1 & 5 & 16.00 & 20.00 & $18.00 \pm 1.58$ & 18.00 \\
\hline P2 & 5 & 2.80 & 4.10 & $3.34 \pm 0.51$ & 3.10 \\
\hline P3 & 5 & 18.80 & 22.30 & $20.32 \pm 1.39$ & 20.00 \\
\hline
\end{tabular}


One Way ANOVA were done to analyze the difference in apoptotic index for each groups. As shown in table I, there was a significant difference in all groups. For the post-hoc analysis, we found significant difference between $K$ and P1 (p=0,001), K and P3 (p=0,001), P1 and P2 $(p=0,001), P 1$ and P3 $(p=0,035), P 2$ and P3 $(p=0,001)$. There was no significant difference between $\mathrm{K}$ and $\mathrm{P} 2(\mathrm{p}=0,792)$.

Table 2. One-Way Anova test for apoptotic index

\begin{tabular}{|c|c|c|}
\hline Group & $\begin{array}{c}\text { Apoptotic index } \\
\text { Mean } \pm \text { SD (\%) }\end{array}$ & \multirow{2}{*}{0} \\
\hline K & $2.18 \pm 0.80$ & \\
\hline P1 & $18.00 \pm 1.58$ & \\
\hline P2 & $3.34 \pm 0.51$ & \\
\hline P3 & $20.32 \pm 1.39$ & \\
\hline
\end{tabular}

Table 3. Post Hoc Analysis for apoptotic index

\begin{tabular}{|c|c|c|c|}
\hline Group & P1 & P2 & P3 \\
\hline $\mathrm{K}$ & $0.001^{*}$ & 0.792 & $0.001^{*}$ \\
\hline P1 & - & $0.001^{*}$ & $0.035^{*}$ \\
\hline P2 & - & - & $0.001^{*}$ \\
\hline
\end{tabular}

Caspase- 8 expression mean in $\mathrm{K}$ group was lower than in P2 $(17.17+1,29$ and $24.61+1,09)$ and in P1 group was lower than P3 $(26,21+1,12$ dan $39,79+$
$1,20)$. The highest mean Caspase- 8 value was found in chemotherapy- Artemisia vulgaris combination.

Table 4. Descriptive analysis for caspase- 8

\begin{tabular}{|c|c|c|c|c|c|}
\hline Group & N & Mean \pm SD (\%) & Median (\%) & Min (\%) & Max (\%) \\
\hline K & 5 & $17.17 \pm 1.29$ & 17.00 & 15.50 & 24.90 \\
\hline P1 & 5 & $26.21 \pm 1.12$ & 26.00 & 23.20 & 27.70 \\
\hline P2 & 5 & $24.61 \pm 1.09$ & 24.70 & 38.60 & 41.60 \\
\hline P3 & 5 & $39.79 \pm 1.20$ & 39.60 & & 25.90 \\
\hline
\end{tabular}

One-Way ANOVA test found that Caspase-8 level were significantly different in all groups $(p=0,001)$.

Table 5. One-Way ANOVA test for caspase-8

\begin{tabular}{|c|l|c|}
\hline Group & Mean \pm SD (\%) & p \\
\hline K & $17.17 \pm 1.29$ & \multirow{2}{*}{$0.001^{*}$} \\
\hline P1 & $26.21 \pm 1.12$ & \\
\hline P2 & $24.61 \pm 1.09$ & \\
\hline P3 & $39.79 \pm 1.20$ & \\
\hline
\end{tabular}

Pearson correlation analysis was done in P3 group, between Caspase- 8 and Apoptotic index. We found a significant positive strong correlation on these two variables. This means that increase in Apoptotic index will be followed by increase in Caspase-8, and vice versa. (Table 6). 
Table 6. Pearsons correlation test

\begin{tabular}{|c|c|c|}
\hline Variable & $\mathbf{r}$ & $\mathbf{p}$ \\
\hline Apoptotic index & \multirow{2}{*}{0.883} & $0.047^{*}$ \\
\hline Caspase-8 & & \\
\hline
\end{tabular}

\section{Discussion}

Apoptotic index was found higher in the chemotherapy-adjuvant group compared with the onlychemotherapy group. This finding was in line with Eunjong $\mathrm{C}$ et.al that stated artemisinin in Artemisia vulgaris had an anticancer effect by apoptosis promotion from estrogen-receptor related pathway. ${ }^{9}$ Another study from Langroudi et.al also mentioned that artemisinin increased immunity by suppresing the T-reg cells. ${ }^{10}$

Chemotherapy was given for only 2 cycles compared with standard 4 cycles recommended for human.11 Significantly higher apoptotic index and Caspase- 8 in combination group showed that Artemisia vulgaris enhanced the apoptotic effect and suppresed cells proliferation compared with chemotherapy alone.

There was higher Caspase- 8 levels in combination group compared with chemotherapy only group. This finding was in line with Jia et. al. study that found artemisinin inhibited G1 phase, increasing reactive oxygen species (ROS) causing mitochondrial potensial membrane collapse and triggered cytochrome-C release to the cytoplasma, activating Caspase-3 mediated apoptosis. ${ }^{12}$ According to $\mathrm{Li}$ et al, artemisinin and its derivative had the pro-apoptotic features by not only from cytochrome-3 release and Bax overexpression, but also by increasing Bax/Bcl-2 ratio, Caspase- 8 activation then activating Bid protein that will induce cytochrome-c release from mitochondria. Cytochromec will be caught by procaspase- 9 and activating Caspase-9 and Caspase-3.7,13 Blazquez et al mentioned Artemisinin might directly interferred with DNA replication in the process of apoptosis induction 14 According to $\mathrm{Mu}$ et al, artemisinin and its derivative causing apoptosis by increasing intracellular calcium and p38 activation. 15 Those findings confirmed the mechanism of artemisinin as the active compund of Artemisia vulgaris in apoptotic process.
This study finding can confirmed the pathway between apoptosis index and caspase-8, shown by the high correlation of those two variables, but there are still other pathway in terms of apoptosis induction. ${ }^{12-}$ 15

Artemisia vulgaris extract has potential for becoming immunomodulatory agent and can be used as adjuvant of the primary therapy, as an alternative source for traditional herbal medicine. We realize that there were still many limitation in this study. We hoped that this study can be continued to the human clinical research.

\section{Conclusion}

Artemisia vulgaris can suppress cell proliferation in $\mathrm{C} 3 \mathrm{H}$ Mice model of Breast adenocarcinoma treated with Adriamycin-Cyclophosphamide in terms of increasing apoptotic index, therefore increasing Caspase-8 levels. We suggested for further studies to better elaborate the toxcicity of this regiment and for searching other factors contributing in increasing apoptotic index and caspase-8 levels..

\section{References}

1. Mugi W. Early detection of cervical cancer and breast cancer in Indonesia 2007 - 2014. Bulletin of Health Data and Information Window. Jakarta: Ministry of Health of the Republic of Indonesia. 2015; 12-5

2. Ministry of Health of the Republic of Indonesia. National Guide to Cancer Management (Breast Cancer). Jakarta: National Committee for Combating Cancer. 2015: 1-10

3. Azwardi R. Recent development of malignant breast tumors. Universa Medicina Trisakti Faculty of Medicine; 2005; 24(4): 190-7

4. Rachel CJ, Nancy ED. Breast Cancer. In: Boyiadzis MM, Frame JN, Kohler DR, Fojo T. Hematology-Oncology Therapy. 2nd ed. New 
York: McGraw-Hill; 2014; 88-190

5. Das AK. Anticancer effect of anti malarial artemisinin compounds. Ann Med Health Sciences Res. 2015; 5(2): 93-102.

6. Yance DR, Sagar SM. Targeting angiogenesis with integrative cancer therapies. Integrative Cancer Therapies. 2006; 5(1): 9-29

7. Gordon $\mathrm{PH}$, Nivatvongs S. Principles and practice of surgery for the colon, rectum, and anus. 3rd ed. Information Healthcare USA. New York. 2007

8. Mescher AL. Junqueira's Basic Histology. 12 th ed. McGraw-Hill. 2010.

9. Trapani JA. Granzymes: A family of lymphocyte granule serine proteases. Genome Biology. 2008; 2 (12)

10. Roitt IM, Delves PJ. Roitt's Essential Immunology. $10^{\text {th }}$ ed. Massachusetts: Blackwell Science, Inc.; 2009; 1-36: 374-95.

11. Donnini S, Morbidelli L, Ziche M, Harmey J. Molecular mechanisms of VEGF-Induced Angiogenesis. Research Gates. July 2011.

12. Masaru A, Mari Y, Hiroaki W, Hiroshi A, Kimiyoshi H, Kiyotaka Y. Immunohistochemical detection of $\mathrm{Ki}-67$ in replicative smooth muscle cell of rabbit carotid arteries after balloon denudation. Strokes 2010; 26: 2328-32.

13. Ozluk V, Tuzlali S, Yavuz E, Derin D, Asoğlu O, Igci A et al. Primary angiosarcoma of the breast: Is Ki-67 proliferation index related to histologic grade? Does steroid hormone receptor expression play a role in the frequency of coexistent pregnancy. Meme sagligi dergisi 2006 Cilt: 2 Sayt: 3. Available from: http://www.moffitt.org/moffittapps/ccj/v9s2 $/ p d f / 28 . p d f$

14. Lyzigubov V, Khozhaenko Y, Usenko V, Antonkuk S, Ovcharenko G, Tikhonkova I et al. Immunohistochemical analysis of Ki-67, PCNA and S6K1/2 expression in human breast cancer. 2007; 27(2): 141-144.
15. Sulistyono, Eko and Marpaung, Jaminton. Study of tuber character and nutritional content dioscore spp, Agronomy Bulletin. 2008; 2(32): 39-43. 